\title{
La política en el mundo obrero en el Tucumán de entreguerras
}

\author{
Politics in the working world of Tucuman in the interwar
}

María Ullivarri*

Resumen: En este trabajo nos interesa analizar las "formas de hacer política" de los trabajadores de una provincia argentina durante los años veinte y treinta, que estuvieron caracterizados por dos procesos en tensión. Por un lado, la "democratización" del proceso político argentino luego de la sanción de una ley que garantizó el de voto obligatorio y universal. Y, por otro, la contundencia de los discursos obreros sobre la necesidad de separar las esferas política y gremial.

Palabras clave: trabajadores, política, Tucumán, entreguerras

\begin{abstract}
In this paper we will analyze the "ways of doing politics" of workers in a province of Tucuman during the interwar period, characterized by two process. On the one hand, the "democratization" of the Argentine political process after the enactment of the Saenz Peña law that guaranteed compulsory and universal male suffrage. And, secondly, the strength of the workers speeches about the need to separate the political and trade union spheres.
\end{abstract}

Key words: workers, politics, Tucuman, interwar period

Recibido: 27 abril 2016

Aceptado: 23 julio 2016

\section{Introducción}

El 24 de febrero de 1946 el Partido Laborista obtuvo el porcentaje más alto de votos del país en la provincia de Tucumán, a $1200 \mathrm{~km}$. de la Capital Federal. En gran medida, ese 69,9\% provino de la estructura y del trabajo político del "movimiento obrero provincial." Esta particularidad le dio al peronismo local una "conformación obrera" y coronó la trayectoria política de los trabajadores tucumanos. ${ }^{1}$ Esta larga trayectoria, que es

\footnotetext{
*Argentina, Dra en Historia, Investigadora del CONICET en el Centro de Estudios e Investigaciones Laborales (CEIL-CONICET). ulliva@gmail.com

${ }^{1}$ Gustavo Rubinstein, Los sindicatos azucareros en los orígenes del peronismo tucumano,Tucumán, Universidad Nacional de Tucumán, 2006; Moira Mackinnon, "El protagonismo del movimiento obrero
} 
la que nos interesa analizar, había ido adquiriendo forma en un marco de tensiones entre el rechazo de la política y la voluntad de participar. ${ }^{2}$ La prescindencia era sin dudas una tradición constitutiva del movimiento obrero y la tajante separación entre las cuestiones de índole gremial y las de índole política había sido un principio sostenido y discutido por las organizaciones sindicales desde sus inicios. Sin embargo en 1912 la ley Sáenz Peña introdujo el voto universal, secreto, obligatorio y masculino y cambió las reglas del juego electoral y, por lo tanto, político. De esta forma, se comenzaron a introducir algunos quiebres en las formas en las cuales la política se presentaba como posibilidad para los trabajadores y a generar disputas internas por los significados y oportunidades que la política ofrecía.

En esa dirección, se sabe que la relación con las dirigencias, con el Estado, con sus organizaciones de clase y con los discursos que los interpelaban, formaban parte del cotidiano político de una gran parte de trabajadores. Pero de manera menos institucionalizada también las lealtades, las obligaciones entre los mismos trabajadores, las organizaciones barriales, culturales y territoriales, los parentescos, la religión, y los vínculos de vecindad, entre otros, también acompañaban o daban forma a lo político en el mundo obrero y moldeaban un universo de referencia y sentido. Muchas de estas interconexiones son a veces difíciles de asir en las fuentes, pero entendemos que la política en sus grafías más o menos explícitas atravesaba toda la vida obrera de una ciudad pequeña como San Miguel de Tucumán, donde muchas veces los dirigentes sindicales y los políticos, eran las mismas personas. Pensarse fuera de esas redes era muy difícil para cualquier trabajador, y por eso mismo, las tensiones entre los discursos de ciertas dirigencias y sus prácticas y relaciones cotidianas eran frecuentes.

Partiendo de este escenario, nos interesa pensar las configuraciones de la politicidad popular y fundamentalmente obrera para comprender mejor los procesos políticos locales. Por eso aquí se pretende analizar cómo los trabajadores tucumanos definieron, se involucraron y experimentaron la política, posicionándonos en la pregunta por las "formas obreras de hacer política", es decir, lo que hicieron, lo que no hicieron y cómo lo hicieron. El problema está situado en el período de entreguerras, pero más concretamente en los años treinta. Este período estuvo caracterizado por dos procesos cruzados, por un lado, la “democratización" del proceso político argentino luego de la sanción de la ley Sáenz Peña

tucumano en la formación del Partido Peronista (1945-1950)", en Sergio Grez Toso, Francisco Zapata y Moira Mackinnon, Formas tempranas de organización obrera, Documento de Trabajo $\mathrm{n}^{\circ} 4$, Instituto Di Tella, Buenos Aires, La Crujía, 2003; Darío Macor y César Tcach (Ed.) La invención del peronismo en el interior del país, Santa Fe, UNL, 2003; Véase también Fernando Siviero, "Trabajadores del sistema agro azucarero tucumano. Una visión desde el debate "trabajadores nuevos-trabajadores viejos", en Actas de las Jornadas Pre Congreso ASET, Tucumán, 2001; SandaGayol, Julio Melon y Mabel Roig, "Peronismo en Tandil ¿Perpetuación conservadora, desprendimiento radical o génesis sindical? 1943-1948”, en Anuario IEHS, $\mathrm{N}^{\circ}$ 3, Tandil, 1988.

${ }^{2}$ La literatura sobre el mundo del trabajo tucumano en la entreguerra no es muy amplia, sin embargo podemos mencionar los trabajos de Eduardo Rosenzvaig, Tucumán, crisis de un modelo y modelo de una crisis, Tucumán, UNT, 1988; María Ullivarri, “Trabajadores, Estado y política en Tucumán, 1930-1943”, Tesis de Doctorado, Universidad de Buenos Aires, 2010; Esteban Piliponsky, “Autonomía y peronización. El sindicalismo tucumano (1943-1946)", Tesina de Licenciatura, Universidad Nacional de Tucumán, 2008. 
y, por otro, la circulación de los discursos sobre la necesidad de separar las esferas política y gremial, muy arraigados en la dirigencia obrera del país.

Suponemos que las nuevas pautas electorales impuestas por la ley no solo extendieron la política hacia los espacios cotidianos del mundo obrero, ligando a los trabajadores a la política a través de sus redes y relaciones, sino que también, en un proceso paralelo, desde sus espacios más orgánicos la política se fue convirtiendo en una forma de lucha y en la estrategia central de los trabajadores para garantizar sus derechos adquiridos y consolidar mayores beneficios. La política, como toda actividad humana se territorializa y produce espacios sociales en su devenir, por eso es allí donde conviene detenerse a analizar el proceso. ${ }^{3}$

En esa dinámica, la propuesta está centrada en un caso provincial, acotado en límites geográficos y con particularidades políticas propias, lo que permite observar más detalladamente la forma en que las directivas nacionales, las propuestas hegemónicas del gobierno y de las centrales obreras, las disputas por el poder al interior del mundo obrero tucumano, las dificultades de acción, los triunfos, los vínculos, las solidaridades y los espacios más amplios de acción obrera, dieron forma a la experiencia de esos trabajadores. Sin embargo, es lícito aclarar que con la elección del espacio geográfico a analizar no me propongo realizar una historia provincial a través del relato de los pormenores de un grupo de obreros, sino que, asumiendo que el mundo social es controversial, rescatar una pieza del conjunto de heterogeneidades presentes en el devenir histórico de los proletarios argentinos. 4

En ese trabajo vamos a utilizar la prensa comercial, tanto tucumana como nacional, prensa obrera del período tanto nacional como provincial, fondos documentales de Juan B. Justo del Archivo General de la Nación, sobre todo lo concerniente al Ministerio del Interior. Y para dar forma a una historia social con la política incluida, o a una historia social de la política y los trabajadores, dividiremos el trabajo en cinco apartados. En una primera parte nos detendremos en la discusión historiográfica sobre los vínculos de los trabajadores con la política, para avanzar luego, en un segundo apartado sobre las configuraciones de la política como disputa dentro del movimiento obrero. En un tercer apartado abordaremos la política como práctica obrera relacionando partidos, frentes y sindicatos. En esa misma línea continuaremos analizando cómo el mundo obrero de la provincia fue construyendo una alternativa política propia en relación con el resto de los grupos políticos actuantes.

\section{Las formas de hacer política}

Nutridas desde diferentes miradas ideológicas, política y prescindencia conformaron dos caras de la trayectoria de lucha de los trabajadores. Cargadas y connotadas de disímiles maneras a lo largo del período analizado, han sido herramientas para disputar, disciplinar y

\footnotetext{
3 Alejandro Grimson et al, La vida política en los barrios populares de Buenos Aires, Buenos Aires, Prometeo, 2009.

4 Bruno Latour, Reassembling the Social: An Introduction to Actor-Network-Theory, Oxford, Oxford University Press, 2005.
} 
organizar el mundo sindical, tanto hacia adentro como también hacia fuera. Por eso entendemos que ambas prácticas y discursos han estado construidos de forma relacional en tanto la una y la otra se definían por oposición, configurando en esa operación, complejas formas de disputar poder dentro del mundo del trabajo organizado. Por fuera de allí, la historiografía señaló que la ley Sáenz Peña produjo un cambio en el rol del Estado, fundamentalmente a partir del desarrollo de una política de integración y de ciertos mecanismos de consenso para grupos obreros con voluntad de negociar. ${ }^{5}$ Este nuevo tablero de juego puso en tensión los discursos y las proclamas de los diferentes espacios sindicales, fundamentalmente porque habilitó la política como terreno de acción y de demanda para amplios sectores sociales. ${ }^{6}$ A pesar de ello, la mayoría de las organizaciones sindicales, o sus dirigentes, atravesaron el período de entreguerras declamando un profundo rechazo a "la política". Y aunque si bien un trabajador organizado era una figura constitutivamente política y la política fue siempre parte constituyente de la vida sindical de ello dan cuenta demandas, marchas, huelgas, presencia pública, reclamos, entrevistas, acciones, solidaridades, organizaciones, etc.-, el sentido electoral y si se quiere, también partidario, no dejaba de generar incomodidades en el conjunto de la dirigencia sindical. Entendían por política la vinculación activa en la vida de los partidos políticos y ríos de tinta corrieron por las publicaciones obreras, en los discursos y también las discusiones entre grupos con diferentes posiciones ideológicas, que destacaron la necesidad de mantener las esferas sindicales separadas de las políticas. ${ }^{7}$

Estas ideas, sin embargo, resumían muchas contradicciones internas del mundo sindical, ya que la presencia de los partidos de izquierda y también del radicalismo era constante en el mundo del trabajo. Asimismo, en muchas ocasiones también los conservadores articulaban espacios de acción con los trabajadores. De esta forma, a pesar de los esfuerzos, pensarse alejados de la política era una tarea difícil, porque las agendas y las vidas personales de muchos trabajadores estaban inextricablemente relacionadas con los espacios de la política territorial e institucional. En ese sentido, la bibliografía coincide en señalar quela iniciación política solía realizarse en comités, en organizaciones, en espacios barriales y también en sindicatos, dando cuenta de que el cambio electoral y el ascenso de

${ }^{5}$ David Rock, El Radicalismo argentino, 1890-1930, Buenos Aires, Amorrortu, 1977; Ricardo Falcón y Ana Monserrat, "Estado, empresas, trabajadores y sindicatos", en R. Falcón (dir.), Nueva Historia Argentina, Democracia, conflicto social y renovación de ideas (1916-1930), t. 6, Buenos Aires, Sudamericana, 2000; Ricardo Falcón, "La relación Estado-sindicatos en la política laboral del primer gobierno de Yrigoyen”, en Estudios Sociales $\mathrm{N}^{\circ}$ 10, Santa Fe: Universidad Nacional del Litoral, 1996; Samuel Baily, Movimiento obrero, nacionalismo y política en la Argentina, Buenos Aires, Hyspamérica, 1985; Fernando Devoto, "De nuevo el acontecimiento: Roque Sáenz Peña, la reforma electoral y el momento político de 1912" en Boletín del Instituto de Historia Argentina y Americana Dr. Emilio Ravignani, número 14, segundo semestre de 1996.

${ }^{6}$ Tulio Halperin Donghi, Vida y muerte de la república verdadera, 1910-1930, Buenos Aires, Ariel, 2000; Leandro Gutiérrez y Luis Alberto Romero, Sectores populares, cultura y política. Buenos Aires en la entreguerras, Buenos Aires, Siglo XXI, 2007.

${ }^{7}$ En varios congresos incluso se anularon diplomas de participantes que ocupaban cargos políticos, de manera que era un asunto serio para algunas dirigencias, especialmente para anarquistas y sindicalistas. Edgardo Bilsky, "Campo político y representaciones sociales: estudio sobre el sindicalismo revolucionario en la Argentina (1904-1910)", Paris, Mimeo, 1988; Eduardo Zimmermann, Eduardo, "Sindicatos y política en la Argentina (1900-1943)", en Revista Libertas ํ2, mayo 1985. 
la Unión Cívica Radical (UCR) tanto en el país como en la provincia transformó la forma de hacer política. ${ }^{8}$

Quizás por ello, el momento político post 1912 visibilizaba que aquellos capaces de adquirir un perfil nítido como actores, es decir, capacidad de presión corporativa (territorial, sindical, etc.) podían alcanzar algún beneficio de las negociaciones. ${ }^{9}$ La ampliación, apertura y complejización de las funciones estatales dieron forma a una política estatal de integración y desarrollo de ciertos mecanismos de consenso para una mayoría obrera dispuesta a negociar. Y en esa dirección, la clave política empezó a aparecer como definitoria, porque allí se jugaban las posibilidades concretas de obtener beneficios. ${ }^{10}$ En esta línea la "politización de los trabajadores" se pronunció como una de las claves explicativas del paso hacia el peronismo. ${ }^{11}$ En esa misma línea, Juan Carlos Torre concluyó que el acercamiento entre esa "vieja guardia sindical" que venía desde los años previos a Perón estaba vinculado con un cambio en la cultura política de los trabajadores. ${ }^{12}$ Por su parte, los trabajos de Nicolás Iñigo Carrera, señalan que las mejoras económicas y el reconocimiento de sus organizaciones y de sus derechos políticos, constituyeron parte central de los objetivos y las estrategias autónomas de la clase trabajadora. Así, tanto sus formas de lucha, como sus alianzas y sus vinculaciones políticas habrían apuntado a consolidar una búsqueda de "inserción democrática" frente a la evaluación sobre la

\footnotetext{
${ }^{8}$ David Rock, "Machine politics in Buenos Aires and the argentine radical party, 1912- 1930", en Journal of Latin American Studies, Vol. 4, No. 2, noviembre de 1972, pp. 233-256; Gardenia Vidal, Radicalismo de Córdoba 1912-1930. Los grupos internos: alianzas, conflictos, ideas, actores, Córdoba, Universidad Nacional de Córdoba, 1995; Leandro Gutiérrez y Luis Alberto Romero, Sectores populares, cultura y política. Buenos Aires en la entreguerras, Buenos Aires, Siglo XXI, 2007; Joel Horowitz, Joel, "Patrones y clientes: el empleo municipal en el Buenos Aires de los primeros gobiernos radicales (1916-1930)", en Desarrollo Económico, Vol. 46, No. 184, enero-marzo de 2007, pp. 569-596, Marcela Ferrari, Los políticos en la república radical: prácticas políticas y construcción de poder (1916-1930), Buenos Aires, Siglo XXI, 2008; Leandro Lichtmajer, "La UCR Tucumana frente al triunfo peronista. Centralización partidaria, declive de los comités y depuración en las prácticas políticas”, en Pablo Pérez Bandra (comp.) Partidos y micropolítica, Buenos Aires, Ed. Suárez, 2011; Luis Alberto Romero, "Madurez de la sociedad civil. 1920-1943", en Roberto Di Stefano, et al, De las cofradías a las organizaciones de la sociedad civil. Historia de la iniciativa asociativa en Argentina. 17761990, Buenos Aires, Edlab, 2002

${ }^{9}$ Los estudios sobre las presiones territoriales están presentes para la ciudad de Buenos Aires en el libro Luciano De Privitellio, Vecinos y ciudadanos. Política y sociedad en la Buenos Aires de entreguerras, Siglo XXI, Buenos Aires, 2003

${ }^{10}$ David Rock El Radicalismo argentino, 1890-1930, Buenos Aires, Amorrortu, 1977; Ricardo Falcón y Ana Monserrat, "Estado, empresas, trabajadores y sindicatos", en R. Falcón (dir.), Nueva Historia Argentina, Democracia, conflicto social y renovación de ideas (1916-1930), t. 6, Buenos Aires, Sudamericana, 2000; Ricardo Falcón, "La relación Estado-sindicatos en la política laboral del primer gobierno de Yrigoyen", en Estudios Sociales No 10, Santa Fe: Universidad Nacional del Litoral, 1996; Tulio Halperin Donghi, Vida y muerte de la república verdadera, 1910-1930, Buenos Aires, Ariel, 2000; Samuel Baily, Movimiento obrero, nacionalismo y política en la Argentina, Buenos Aires, Hyspamérica, 1985.

${ }^{11}$ Miguel Murmis y Juan Carlos Portantiero, Estudios sobre los orígenes del peronismo, Buenos Aires, Siglo XXI, 2004 (Primera edición en 1974), Hugo Del Campo, Sindicalismo y Peronismo. Los Comienzos de un Vínculo Perdurable, Buenos Aires, Siglo XXI, 2005, (Primera edición de 1983); Louise Doyon, Perón y los trabajadores, Buenos Aires, Siglo XXI, 2006.

${ }^{12}$ Juan Carlos Torre, La vieja guardia sindical y Perón, Buenos Aires, Eduntref, 2006
} 
imposibilidad, en ese contexto, de superar el sistema burgués. ${ }^{13}$ Coducido por la Confederación General del Trabajo (CGT), el movimiento obrero argentino coqueteaba con la política a partir de las tensiones puestas de manifiesto en las discusiones de su dirigencia. ${ }^{14}$ De hecho, como señala Hernán Camarero, fue la crítica al apoliticismo uno de los argumentos centrales de la ruptura de la CGT en 1935 a través de la "toma" del local de la calle Independencia, aunque la nueva conducción, frente a la presión comunista, volvió a fijar un rumbo prescindente. ${ }^{15}$ Era, de alguna manera, la relación con los partidos de izquierda la que iba marcando el rumbo de las relaciones internas y la que habilitaba o no las posibilidades de discutir política en el seno del universo sindical. ${ }^{16} \mathrm{Y}$ esas discusiones avanzaron también sobre los espacios multisectoriales como "frentes populares" o "comités antifascistas". ${ }^{17}$ La pertenencia a un entramado discursivo europeo en clave antifascista constituyó un hito movilizador insoslayable y entroncó con un discurso obrero que siempre estuvo cómodo en el internacionalismo. Sin embargo, a la hora de resignificar la disputa interna, algunas investigaciones dan cuenta del crecimiento de una idea de nación y de identidad nacional que habría despertado en los trabajadores la necesidad de demandar su incorporación al mapa político. En ese proceso se habría articulado la demanda de una mayor actividad en la política institucional como herramienta la defensa de los intereses económicos "nacionales". 18

El sentido polisémico de la práctica política, no obstante, se volvía más áspero cuando se trataba de la participación electoral. Ninguna organización, decía Abad de Santillán "podía convertirse en gestora o reclutadora de votos para el triunfo político de ningún partido."19 Estaban convencidos de que la posibilidad de que el voto se convierta en una herramienta de democratización no modificaba el antiguo orden de cosas, porque aunque "el Estado aparece como ejerciendo el papel de órgano neutralizador de la lucha de

\footnotetext{
${ }^{13}$ Nicolás Iñigo Carrera, La estrategia de la clase obrera, 1936, Buenos Aires, Ed. Madres de Plaza de Mayo, 2004 y Nicolás Iñigo Carrera, "Formas de lucha de la clase obrera y organizaciones políticas en la Argentina de los años '30", Documento de trabajo PIMSA, Año II, No 2, 1998.

${ }^{14}$ Eduardo Zimmermann, Eduardo, “Sindicatos y política en la Argentina (1900-1943)”, en Revista Libertas $\mathrm{N}^{\circ}$ 2, mayo.

${ }^{15}$ Hernán Camarero, "La izquierda partidaria y la CGT, 1935-1939. Las disputas entre el frentpopulismo comunista y la prescindencia apolítica de la dirección sindicalista" en Actas de las XIII Jornadas Interescuelas/Departamentos de Historia, Catamarca, agosto, 2011.

${ }^{16}$ Hernán Camarero, "La experiencia comunista en el mundo de los trabajadores, 1925-1935", Prismas, $\mathrm{N}^{\circ}$ 6, Quilmes, 2002, Mirta Lobato, "Rojos. Algunas reflexiones sobre las relaciones entre los comunistas y el mundo del trabajo en la década de 1930”, en Prismas, Quilmes, $N^{\circ}$ 6, 2002; Celia, Durruty, Clase Obrera y Peronismo, Buenos Aires, Pasado y Presente, 1969.

${ }^{17}$ Ricardo Pasolini, "El antifascismo como problema: perspectivas historiográficas y miradas locales", en Boletín Bibliográfico Electrónico del Programa Buenos Aires de historia política, en http://historiapolitica.com/boletin, Año 1, $\mathrm{N}^{\circ}$ 2, septiembre de 2008, Ricardo Pasolini, "El nacimiento de una sensibilidad política. Cultura antifascista, comunismo y nación en Argentina: Entre la A.I.A.P.E. y el Congreso Argentino de la Cultura, 1935-1955”, en Desarrollo Económico, n 179, Oct-Dic., 2005; Andrés Bisso, Acción Argentina. Un antifascismo nacional en tiempos de guerra mundial, Buenos Aires, Prometeo, 2005.

${ }^{18}$ Hiroshi Matsushita, Movimiento obrero argentino 1930-1945, Buenos Aires, Hyspamérica, 1983; Joel Horowitz, Los sindicatos, el Estado y el surgimiento de Perón, 1930-1946, Buenos Aires, Eduntref, 2004.

${ }^{19}$ Diego Abad de Santillán, La F.O.R.A., Buenos Aires, Editorial Proyección, 1971, p. 49
} 
intereses [...] basta que se produzca el desequilibrio en las forzosas relaciones entre patrón y obrero [...] para que el gobierno, cualquiera sea su origen [...] ponga todas sus fuerzas al servicio de la minoría privilegiada." ${ }^{20}$ Los anarquistas de hecho, habían pensado esa posición como un bastión, convencidos de que el verdadero daño a la burguesía se hacía desde la huelga. ${ }^{21}$ Las diferencias con los socialistas eran evidentes, no solo porque estos rechazaba la huelga en si misma, sino también porque para estos, como afirmaba su líder, "la política es un campo donde la clase trabajadora tiene que pelear por sus más grandes intereses actuales y en el que desde ya puede obtener y obtiene grandes ventajas." 22 Pero esto se haría "dando sus votos a los partidos que tienen en sus programas reformas, concretas en pro de la legislación obrera." ${ }^{23}$ Los trabajadores más cercanos al socialismo eran interpelados para votar al ala política del partido, mientras que los comunistas bregaban por la participación a partir de un estrecho vínculo entre partido y sindicato. Los sindicalistas estaban en una posición intermedia, que les permitía manejarse con más libertad a la hora de construir estrategias, pero lo político había sido solo una consecuencia de las relaciones de producción. ${ }^{24}$ Para los sindicalistas, en el mismo sentido, la disposición a la negociación no implicaba la aceptación del sistema político existente. El vínculo anidaba en la búsqueda de interlocutores en la estructura burocrática del estado para poder plantear los intereses de los trabajadores y sus organizaciones. Juan Carlos Torre afirma que para una estrategia de acción sindical que privilegia instalarse en la esfera de los conflictos sociales, el origen de los gobiernos cobraba un carácter accesorio "o remite, en todo caso, a una misma e inmutable dominación burguesa." 25

Pero en líneas generales la mirada sobre la contemporaneidad política que la dibujaba sojuzgadora e hipócrita o exigía un "mantenerse al margen" era disputada por cierto sector de la dirigencia sindical, pero no por las bases. En ese sentido, intentando no ser parte de ese escenario dibujado como decadente, los anarquistas llamaban a alejarse de la tentación de ciudadanía, pero muchos anarquistas votaban al radicalismo. ${ }^{26}$ También lo hacían muchos sindicalistas y militantes de sindicatos socialistas que a la hora de elegir gobiernos se inclinaban siempre por los partidos mayoritarios.

Esta disociación de lealtades, señala Juan Carlos Torre, estaba vinculada posiblemente con la existencia de un sistema político que permitía el acceso indirecto de grupos importantes de trabajadores a los recursos distribuidos por el Estado. ${ }^{27}$ Rubén Íscaro, el dirigente comunista, explicaba el bajo éxito electoral de la izquierda señalando

\footnotetext{
${ }^{20}$ La Protesta, 03/09/1929

${ }^{21}$ Sebastián Marotta, El movimiento sindical argentino, Buenos Aires, Ediciones Libera, 1975, tomo I.

${ }^{22}$ Juan B. Justo, Obras Completas de Juan B. Justo, Buenos Aires, La Vanguardia, 1978, p. 21

${ }^{23}$ Jacinto Oddone, Gremialismo proletario argentino, Buenos Aires, La Vanguardia, p. 196

${ }^{24}$ Edgardo Bilsky, "Campo político y representaciones sociales: estudio sobre el sindicalismo revolucionario en la Argentina (1904-1910)", Paris, Mimeo, 1988

${ }^{25}$ Juan Carlos Torre, "La trayectoria de la vieja guardia sindical antes del peronismo", en Waldo Ansaldi, Alfredo Pucciarelli y José Villarroel, José, Representaciones inconclusas. Las clases, los actores y los discursos de la memoria, 1912-1946, Buenos Aires, Biblos, 1995, 296-297.

${ }^{26}$ Dora Barrancos, Anarquismo, educación y costumbres en la Argentina de principios de siglo, Ed. Contrapunto, Buenos Aires, 1990.

${ }^{27}$ Juan Carlos Torre, Ensayos sobre movimiento obrero y peronismo, Siglo XXI, Buenos Aires, 2012.
} 
que la clase trabajadora no comprendía "el carácter de las fuerzas políticas actuantes en el país y, especialmente, del radicalismo." ${ }^{28}$ En ese sentido, parte de esa situación era atribuida al "apoliticismo" de los dirigentes obreros. Algo parecido decían los dirigentes socialistas, para quienes la estricta postura de prescindencia a veces desdibujaba las diferencias entre, por ejemplo, el Partido Socialista (PS) y los partidos de la "política criolla" dificultando las opciones para los trabajadores. ${ }^{29}$

Sin embargo, es difícil presentar un cuadro acabado sobre las voces en disputa en el escenario obrero. En parte porque la bibliografía presenta cierta reificación de los actores. El "movimiento obrero", la "dirigencia sindical", la "CGT", la "vieja guardia sindical", etc., son todos actores colectivos cuyas acciones aparecen interpretadas en conjunto y, por lo tanto, desprovistas de matices y de variables regionales. El surgimiento de una agenda historiográfica más amplia, remite a la necesidad de seguir preguntarnos por las tensiones constitutivas del sindicalismo argentino en su conjunto. ${ }^{30}$ En esa dirección, la complejidad de la trama social y política que vinculaba a los obreros con la voluntad de participación se construyó historiográficamente desde perspectivas amplias donde hombres y mujeres, dirigentes, partidos y alianzas de diversa índole, se movían en un clima de época donde difícilmente sus protagonistas podían quedar al margen de la discusión y la práctica política.

\section{El crecimiento de la idea}

A partir de la ampliación democrática (masculina) la vida política se acrecentó y la participación electoral fue creciendo, hasta alcanzar su pico más alto en 1928, cuando votó el 80,1\% del padrón. ${ }^{31}$ Paralelamente, la maquinaria política se fue aceitando, los partidos ampliaron su infraestructura, los comités se extendieron territorialmente y la política comenzó a incorporar elementos rituales y míticos. ${ }^{32} \mathrm{Al}$ mismo ritmo que se extendía por la sociedad, se habilitaban nuevas formas de articular las demandas sociales con el Estado tras nuevas reglas del juego. ${ }^{33}$ A ese nuevo escenario, la sociedad fue respondiendo a partir de la conformación de asociaciones y organizaciones que se creaban para gestionar y para peticionar a las autoridades con el fin de generar mejoras en sus vidas, sus barrios y sus condiciones de trabajo. De esta nueva configuración social y política que adquirió forma tras la puesta en vigencia de la Ley Sáenz Peña los trabajadores (organizados) no estuvieron ajenos.

\footnotetext{
${ }^{28}$ Rubens Íscaro, Historia del movimiento sindical, Buenos Aires, Ciencias del Hombre, 1973, tomo IV, 26.

${ }^{29}$ Leandro García, "Animarse a la prescindencia: La lógica de construcción político ideológico de la corriente sindicalista en la CGT (1930-1935)," Tesis de Maestría, Universidad Nacional de La Plata. Facultad de Humanidades y Ciencias de la Educación, 2013.

30 Juan Suriano, "Los dilemas actuales de la historia de los trabajadores", en Jorge Gelman (Comp.) La historia económica en la encrucijada, Buenos Aires, Prometeo, 2006, p. 286

${ }^{31}$ Luis Alberto Romero, "Sociedad democrática y política nacional y popular: la Argentina en la primera mitad del siglo XX", Estudios Sociales, 46, primer semestre de 2014, pp. 145-170.

${ }^{32}$ Ana Bertoni y Luciano De Privitellio, "Introducción", en: Lilia Ana Bertoni y Luciano de Privitellio (eds.), Conflictos en democracia. La vida política argentina entre dos siglos, Buenos Aires, Siglo XXI, 2009.

${ }^{33}$ Tulio Halperin Donghi, Vida y muerte de la República Verdadera, 1910-1930. Buenos Aires, Ariel, 2000.
} 
En Tucumán el proceso fue similar, sin embargo, al finalizar los años veinte el entusiasmo parecía haber ido decayendo. Parte de ese situación aparece visible en una sociedad que se mostraba cansada y agobiada por las prácticas del gobierno depuesto, centradas -según palabras de sus detractores- en el "caudillismo, el comité y las clientelas." ${ }^{34}$ En esta sensación social de pesadumbre confluían dos horizontes: por un lado, el desprestigio del gobierno del radical personalista Sortheix en el ámbito provincial y, por otro, el desgaste del yrigoyenismo a nivel nacional.

Desde la sanción de la ley Sáenz Peña la provincia había estado gobernada por políticos de la Unión Cívica Radical (UCR). Las críticas recibidas por estas gestiones respecto a lo que algunos sectores -especialmente conservadores- consideraban "demagogia radical" estaban asociadas con el interés del Estado por vincularse con los trabajadores en el marco del proceso de apertura democrática. ${ }^{35}$ Sin embargo, acorralado por problemas económicos, el gobierno de Sortheix -que asumió en 1928-comenzó a quebrar esa tradición de negociación y diálogo que se había venido construyendo a lo largo de la década del veinte y esta fractura en el vínculo con el Estado profundizó entre los proletarios de la provincia la idea de que las autoridades no podían brindar soluciones a sus problemas ni laborales ni cotidianos y que la política, de alguna manera, no era la solución. ${ }^{36}$ Así lo hicieron saber cuando en marzo de 1930 se negaron a responder al llamado del gobernador para intentar solucionar una huelga general. "Que esperen los ricos y el gobernador" indicaron; "que también nosotros hemos esperado dieciocho días con nuestra miseria y nuestro dolor a cuestas, y ellos no se han afligido por nosotros." ${ }^{37}$ En tal sentido, estos discursos triunfales repetidos por un sector de la dirigencia sindical adquirieron un significado más tangible y movilizador a medida que la crisis económica mundial comenzaba a mostrar consecuencias y la desocupación, la carestía y la miseria empezaron a regir la vida cotidiana. Quizás por ello, el desenlace perturbador de la primera

\footnotetext{
${ }^{34}$ Matías González “La construcción de las identidades políticas en Tucumán: lógicas populistas: 1916-1934”, en Actas de las I Jornadas de Jóvenes Investigadores, UNT-AUGM, Tucumán, Junio 2007

${ }^{35}$ María Celia Bravo, "El populismo radical en Tucumán en la década de 1920: conflictos azucareros y crisis política”, en Alfredo Bolsi (Comp.), El complejo azucarero en Tucumán. Dinámica y articulaciones. UNT, Versión CD Rom, 2002; Alejandra Landaburu, "Estado, empresarios y obreros: los empresarios y el Departamento de Trabajo ante las huelgas de 1919 en Tucumán”, en Actas de las XI Jornadas Interescuelas/Departamentos de Historia, Universidad Nacional de Tucumán, Tucumán, 2007; Matias González, "Distintas medidas y relación gobierno-clases trabajadoras durante el gobierno de Bascary. 19171919”, Documento de Trabajo, CAE, Tucumán, s/f, Inédito. David Rock, El Radicalismo argentino, 18901930, Buenos Aires, Amorrortu, 1977; Ricardo Falcón, "La relación Estado-sindicatos en la política laboral del primer gobierno de Yrigoyen”, en Estudios Sociales, No 10, a. VI, $1^{\circ}$ semestre de 1996; Ricardo Falcón, "Política laboral y relaciones Estado-sindicatos en el gobierno de Hipólito Yrigoyen (1916-1922), en Juan Suriano (Comp.), La cuestión social en Argentina 1870-1943, Buenos Aires, La Colmena, 2000; Ricardo Falcón y Ana Montserrat, "Estado, empresas, trabajadores y sindicatos", en FALCÓN, Ricardo, (Dir.), Democracia, conflicto social y renovación de ideas (1916-1930), Colección Nueva Historia Argentina, Tomo 6, Buenos Aires, Sudamericana, 2000; Samuel Baily, Movimiento obrero, nacionalismo y política en la Argentina, Buenos Aires, Hyspamérica, 1985.

${ }^{36}$ Tierra Libre, Año 1, N 5, II Época, Tucumán, Mayo de 1928.

${ }^{37}$ Palabras de un obrero apellidado Montenegro, miembro del Comité de Huelga de los albañiles. La Gaceta, 12/03/1930.
} 
experiencia democrática que se había abierto en 1916 tras el triunfo de Hipólito Yrigoyen, fue recibido con relativa indiferencia por los dirigentes sindicales.

Lo cierto es que luego del golpe de estado de septiembre de 1930, las organizaciones obreras que solían ser más numerosos, como la anarquista Federación Obrera Regional Argentina (FORA), habían visto disminuir su influencia y no lograban disimular el pesimismo. "De seguir así", decían en su órgano de prensa, "seremos absorbidos por el ambiente hasta tal punto que no quedará nada después de tantos años de sacrificios." Había pues que "sacar fuerzas de flaquezas, hasta levantar las organizaciones." ${ }^{38}$ Como parte de esa estrategia, poco tiempo después del golpe, la Federación Obrera Local Tucumana (FOLT), rama provincial de la FORA, echó de la Sociedad de Resistencia de Obreros Albañiles a los trabajadores que habían liderado las listas comunistas en los años veinte. Los dirigentes foristas esgrimieron que los expulsaban "por hacer política". ${ }^{39}$ En ese sentido, "hacer política" abarcaba a "todos los que hagan propaganda política o acepten candidaturas" ${ }^{\prime 0}$ y esto constituía un asunto disruptivo para la organización obrera.

Ciertamente el Partido Comunista (PC) comenzaba a arremeter con fuerza en el mundo del trabajo tucumano, en un escenario que no era el mejor, porque la represión extendida por el gobierno de facto, fragmentaba día a día el pequeño organigrama sindical de la provincia. No era sencillo lidiar con el llamado comunista a extinguir "los arcaicos métodos de lucha anarco-sindicalistas." ${ }^{41}$ Sus llamados reclamando la participación política de la clase obrera y fomentando un estrecho vínculo entre Partido y sindicato, se sembraban en un territorio pantanoso que no estaba muy dispuesto a escuchar. Su idea final era convertir el PC, a través de la estrategia del frente único, en un partido comunista de masas, cuyo plan para difundir el programa estaba acompañado del ataque a los dirigentes adversarios. $^{42}$ Así se proponían "desenmascarar a sus jefes ligados al irigoyenismo" 43 donde englobaban a la CGT recién fundada y también a los anarquistas.

Por su parte, la CGT, conformada por socialistas y sindicalistas, intentaba hacer pie en las provincias a través de giras para dar conferencias o colaborar con la fundación de uniones obreras. A Tucumán llegó el "delegado confederal" Domingo Heredia para organizar una conferencia donde señaló "la necesidad urgente de organizar a los trabajadores en sus respectivos sindicatos y constituir la Federación Obrera Local". ${ }^{44} \mathrm{Y}$ aunque la propuesta cegetista no encontró interlocutores dispuestos a embanderarse detrás

\footnotetext{
38"¿Qué hacemos?", en Tierra Libre, Año 2, № 9, Tucumán, Abril de 1929.

${ }^{39}$ En este sentido fueron alejados del sindicato Benito Salvatierra, Alfredo Tejo, Andrés Sánchez, Juan Rivadeneira y Jesús Barrientos por comunistas, y Segundo Fernández por socialista independiente. "Sociedad de Resistencia de Obreros Albañiles y Anexos”, en Tierra Libre, Año 3, N¹2, Tucumán, Octubre de 1930.

${ }^{40}$ Tierra Libre, Año 3, N 12 , Tucumán, Octubre de 1930.

41 "Las grandes huelgas de la madera y construcción y su repercusión en el interior. Colaboración de Tucumán", en Solidaridad Obrera, Año 1, N¹, Buenos Aires, 11 de diciembre de 1936

${ }^{42}$ Boletín Interno, editado por el Agit-Prop del Partido Comunista, Buenos Aires, febrero 1 de 1932, Legajo del PC, $\mathrm{N}^{\circ} 3362$, AGN.

43"La situación de la clase obrera.... (Título completo ilegible)", Documento del Partido Comunista, Junio de 1931, Legajo del PC, N³362, Archivo General de la Nación (AGN), pp. 2-6.

${ }^{44}$ La Gaceta, 27/01/1932
} 
de ella, la organización de una central provincial no era un tema ajeno a los intereses de los sindicatos tucumanos. Un tiempo antes del arribo del delegado cegetista, a mediados de 1931, cuando la actividad sindical comenzó a reactivarse tras el golpe, se materializó el primer intento de la década para organizar una central obrera en la provincia. La Sociedad de Artes Gráficas invitó a todos los sindicatos a enviar delegados a una reunión para discutir un plan de unidad con marcada impronta sindicalista, "libre de ideologías y tendencias políticas," 45 ya que "se erigirá únicamente con carácter gremial, única forma de mantener la integridad y unión de la representación obrera." ${ }^{46}$ La CGT, por su parte, llamaba a desarmar cualquier esbozo de "autonomía" que no se alineara con su estructura "puesto que carentes del apoyo solidario, desaparecen con suma facilidad al menor amago reaccionario." 47

Pero la idea de armar espacios alejados de la política resultaba inconcebible para los trabajadores comunistas que, expulsados de la FORA, buscaron otros nichos de inserción fomentando la creación de sindicatos "autónomos" e intentaron marcar agenda política en la dinámica obrera provincial. ${ }^{48}$ De esta forma, en ese juego de poderes lo que se discutía, además del problema de la dirección del movimiento sindical, era el tema de la política, o su contracara, la prescindencia. Y esa era una batalla que comenzaba a instalarse con fuerza, tanto dentro de la CGT, contra un sector del socialismo a quien acusaban de "tener el deseo de acoplar las actividades sindicales a la suerte de un partido político;" como fuera de la central, con la presión de los comunistas. ${ }^{49}$

Estas tensiones pasaban de la Capital a las provincias a través de los sindicatos locales y ponían en discusión cotidianamente la estrategia del movimiento obrero mayoritario, aquella que consistía en sostener el statu quo para defender a la organización de las posibles reacciones gubernamentales a partir asumir una postura de prescindencia. ${ }^{50}$ Frente a eso, un sector del mundo sindical, fundamentalmente traccionado por el comunismo y por un sector del socialismo, parecía ir tomando la decisión de proyectarse a la arena política cortando con la tradicional postura de prescindencia. ${ }^{51}$ En esa dirección, a fines de 1935 la conducción CGT fue cooptada por los sectores disconformes. Esto provocó un cambio en los vínculos de la central con los gremios que la componían a partir de la voluntad manifiesta de dar constitución orgánica a la entidad llamando a un congreso constituyente. ${ }^{52}$ Este cambió mejoró también los vínculos de la central sindical con los gremios del interior, incorporando representantes de varias partes del país. Por otro lado, también se incorporaron los comunistas que habían crecido notablemente.

\footnotetext{
${ }^{45}$ La Gaceta, 18/05/1931 y La Gaceta, 20/06/1932.

${ }^{46}$ La Gaceta, 18/05/1931.

${ }^{47}$ Boletín CGT, 25/06/1933.

48“La situación de la clase obrera... (título completo ilegible)", Documento del Partido Comunista, Junio de 1931, Legajo del PC, N 3362, Fondo Agustín P. Justo, Archivo General de la Nación.

${ }^{49}$ Boletín CGT, 25/10/1933 y MARTÍNEZ, Ilana (2009), "Conflictos, disidencia y radicalización. El ala de izquierda del Partido Socialista argentino, 1929-1937”, en Actas II Jornadas Nacionales de Historia Social, La Falda.

${ }^{50}$ LouiseDoyon, Perón y los trabajadores, Buenos Aires, Ed. Siglo XXI, 2006.

${ }^{51}$ Doyon, op cit.

${ }^{52}$ Hiroshi Matsushita, Movimiento obrero argentino 1930-1945, Buenos Aires, Hyspamérica, 1983
} 
Esto generó un nuevo escenario en la conducción de la mayor parte del movimiento obrero nacional. En efecto, para el comunismo, ya concentrado en su etapa frentepopulista, el ingreso a la CGT significaba la posibilidad de orientar al movimiento obrero en una línea antiimperialista, antifascista y, sobre todo, contraria a la neutralidad ideológica y política. ${ }^{53}$ Sin embargo, los comunistas todavía representaban el fantasma interno. Y por eso, si bien fue la crítica al apoliticismo uno de los argumentos centrales de la ruptura de la CGT en 1935, frente a la presión comunista, la nueva conducción volvió a fijar un rumbo prescindente. De esta forma, la disputa contra el comunismo alcanzó nacionalmente status de discurso prescindente.

\section{La construcción de un espacio}

La política por fuera del movimiento sindical funcionaba de manera muy distinta a ese escenario de disputas internas entre gremios. Obligaba a articular más forzadamente el trabajo territorial y a ampliar el universo de variables a discutir, negociar y disputar. Pero también, en el escenario político los trabajadores eran valiosos recursos en las disputas por el poder. En esa dirección, por fuera del universo gremial, la política también tenía un sentido coercitivo. Así, a pesar de que las leyes garantizaban el voto universal masculino, elegir libremente no siempre era una opción para los trabajadores. Muchos de ellos, mucho más en el campo que en la ciudad, denunciaban que "les está vedado, por la fuerza y un sistema de coerción montado en el propio feudo, votar libremente." 54 Este tipo de denuncias atravesaron los años veinte y treinta. Los trabajadores acusaban que solo conocían la política de los patrones, "los liberales era el partido político que tenía el establecimiento aquí. Y había que ser liberal nomás, no había tramoya."55

Sin embargo, a pesar de esas prácticas, también se registraron muchas denuncias de cesantías "por negarse a votar a los liberales," 56 que de alguna manera expresaban la voluntad de resistir las imposiciones patronales. En ese sentido, la política comenzó a no ser ajena a los trabajadores que a través de comités en barrios y pueblos, fundados para apoyar tanto a conservadores como a radicales, se acercaban a participar. ${ }^{57}$ Los radicales, prácticamente imbatibles en las urnas hasta 1942, incluso habían armado una Unión Obrera Radical que apoyaba a la fracción "sovietista" del radicalismo, cuyo trabajo más importante fue el intento de lograr la sanción de las leyes de salario mínimo y de jornada laboral en la

\footnotetext{
${ }^{53}$ Hernán Camarero, "La izquierda partidaria y la CGT, 1935-1939. Las disputas entre el frentpopulismo comunista y la prescindencia apolítica de la dirección sindicalista" en Actas de las XIII Jornadas Interescuelas/Departamentos de Historia, Catamarca, agosto, 2011

${ }^{54}$ La Gaceta, 29/08/1942.

${ }^{55}$ Josefina Centurión, "Cultura y Sociabilidad en los Pueblos Azucareros", Tesina de Licenciatura, Universidad Nacional de Tucumán, 2000, 100

${ }^{56}$ El Trabajo, 25/05/1924

${ }^{57}$ Leandro Lichtmajer, "La UCR Tucumana frente al triunfo peronista. Centralización partidaria, declive de los comités y depuración de las prácticas políticas", en Pablo Pérez Branda (comp.) Partidos y Micropolítica, Ed. Suárez, Mar del Plata, 2011.
} 
industria azucarera. ${ }^{58}$ Los socialistas, por su parte, habían tenido un desempeño electoral bastante respetable durante los años veinte, con cinco concejales en las ciudades más importantes de la provincia y dos diputados provinciales. Con la abstención de la Unión Cívica Radical en las elecciones de 1931 obtuvieron nuevamente dos diputados provinciales, cinco electores, un senador y cinco concejales. El PS había participado de elecciones desde 1917, mientras que el Partido Comunista lo hizo por primera vez en 1927 en elecciones municipales, obteniendo 80 votos y repitió su participación en 1929.

En ese sentido, los procesos electorales se volvían instancias fundamentales donde la politización se acentuaba, se visibilizaban y se ponían en discusión los modos de ver el mundo, los rituales, las formas morales de entender la política, las alianzas y las aspiraciones de los grupos. En la provincia de Tucumán y especialmente en la capital, el porcentaje de votantes crecía exponencialmente. En abril de 1924 votó apenas el 46\% del padrón, mientras que a en 1929 el porcentaje había llegado al 63,50\% y superó el 70\% en los años treinta. A través de la organización en comités y centros políticos, así como también en la participación electoral, la idea de actuar políticamente y no solo ir a votar, estaba muy arraigada en la población.

Algunos autores afirman que esa voluntad fue desapareciendo a partir del golpe de estado de 1930, cuando se produjo una "desmovilización de los sectores populares" hacia espacios con mayor autonomía de los partidos. ${ }^{59}$ Sin embargo, a la luz de las evidencias, estas afirmaciones están lejos de reflejar el vigor de la prácticas políticas de parte importante de los sectores populares quienes, atravesados por la intensidad de los procesos políticos locales, pero también los europeos, se movilizaron políticamente con un apasionamiento que no tenía precedentes. En ese sentido, entre 1930 y 1943 se vivieron en el país las consecuencias de una crisis económica cruenta, el derrocamiento de un gobierno democrático y el desprestigio de las instituciones liberales y de toda la ingeniería institucional articulada en torno a la ley Sáenz Peña. Estas situaciones franquearon las vidas de todos los hombres y mujeres trabajadores/as que debieron adaptarse a los vaivenes de un régimen que, apoyado en la exclusión, recortó los márgenes de la ciudadanía y potenció las sensaciones de explotación, de desarraigo político y de injusticia social. Esta particular situación, que afectó profundamente el mundo del trabajo y a los hogares obreros, introdujo en la dinámica del cotidiano la necesidad de construir nuevas estrategias para lidiar con la incertidumbre que crecía.

El descontento generado por el gobierno que siguió al golpe de estado llevó al movimiento obrero a generar espacios de mucha conflictividad laboral. Incluso algunas voces llamaban la atención sobre "el estado de subversión" que vivía la provincia. ${ }^{60}$ Además de las acciones clásicas, el movimiento sindical también coqueteó con la política a

\footnotetext{
${ }^{58}$ Los radicales habían ganado todas las elecciones provinciales, salvo el período en el que duró la abstención declarada por el comité nacional a partir de 1931, que los radicales tucumanos rompieron en 1934. María Celia Bravo, Campesinos, azúcar y política: cañeros, acción corporativa y vida política en Tucumán (18951930), Rosario, Prohistoria, 2009 y Alejandra Landaburu, "Los empresarios azucareros y la cuestión social. Tucumán 1916-1930", Tesis de Doctorado-Universidad Nacional de Tucumán, Tucumán, 2014.

${ }^{59}$ Leandro Gutiérrez y Luis Alberto Romero, Sectores populares, cultura y política. Buenos Aires en la entreguerra, Buenos Aires, Siglo XXI, 2007.

${ }^{60}$ La Gaceta, 17/06/1932
} 
partir de la participación en las performances que los estudiantes universitarios realizaban burlándose del gobierno. Estas llegaron tan lejos como a ganar una elección complementaria de legisladores, que luego fue anulada, presentando un partido político "obrero-estudiantil" que llevó de candidatos a dos hombres con problemas mentales como candidatos. Un tiempo después la provincia fue intervenida, y aunque nadie podría afirmar con contundencia que los trabajadores contribuyeron a la caída del gobernador Juan Luis Nougués tras la intervención de la provincia, sí era posible aseverar que no estuvieron del todo ajenos a las circunstancias.

En 1934 la Unión Cívica Radical tucumana, luego de negarse a participar de los comicios desde 1931, desobedeció el mandato nacional, se presentó a elecciones y las ganó. Lo mismo sucedió en Córdoba y Entre Ríos, convirtiendo a estas tres provincias en bastiones radicales en un escenario conservador. De esa forma, la llegada de gobiernos de la UCR cambió el escenario político a partir de un nuevo proceso de apertura estatal respecto al mundo de los trabajadores, pero que también abarcó a las organizaciones políticas y comités que estaban estructurados en torno a problemas como la República Española, el nazismo, el antifascismo, la lucha contra "la reacción", etc. ${ }^{61} \mathrm{Y}$ en esa coincidencia entre movilización política y apertura estatal, se consolidó un vínculo entre trabajadores y dirigentes políticos forjado en comités y espacios de lucha antifascista donde cotidianamente se discutían los acontecimientos europeos. Muestras de esos lazos estaban presentes en las defensas que los abogados vinculados a los comités hacían de los presos obreros, pero también aparecieron en los intentos de un sector del movimiento obrero, encabezado por el Sindicato de Ladrilleros y el de la Construcción de conformar un Frente Popular en alianza con el PC, los radicales y los socialistas.

Las dificultades para conformar la alianza cuajaron en la disputa interna del socialismo y los esfuerzos fueron tenazmente boicoteados por un sector de la dirigencia del PS que decidió unirse solo "con agrupaciones responsables y partidos orgánicos." 62 Sus proclamas se dirigían a la rama disidente de su partido que, embanderada detrás del mendocino Benitto Marianetti y reclamando un giro a la izquierda, se había llevado consigo casi toda el ala sindical del socialismo tucumano para formar un nuevo partido, el Socialista Obrero (PSO). ${ }^{63}$ Este dato no es menor, porque en la disputa entre grupos socialistas, la cuestión de la política jugaba un rol central. Los disidentes tenían como meta conformar un espacio obrero que marque el rumbo de la agenda política y de esta forma conquistar los

\footnotetext{
${ }^{61}$ María Ullivarri, "Política, antifascismo y movimiento obrero. Tucumán 1935-1936" en Población \& Sociedad, Vol. 16, 2009, pp. 283-316 y María Ullivarri, "Trabajadores, Estado y política durante las gobernaciones radicales en Tucumán. 1935-1943”, Anuario Centro de Estudios Históricos Carlos Segretti, N¹1, Córdoba, 2011; María José Ortiz Bergia, De caridades y derechos. La construcción de políticas sociales en el interior argentino. Córdoba (1930-1943). Córdoba, CEH “Prof. Carlos S. A. Segreti”, 2009,

${ }^{62}$ Discurso de Emilio López, El Orden, 02/05/1937. Los socialistas se presentaron a elecciones y avanzaron bastante en su caudal de votos, llegando a alcanzar 3829 votos, quedando en tercer lugar en las elecciones nacionales de septiembre de 1937, superando ampliamente su performance de las elecciones provinciales de marzo.

${ }^{63}$ María Ullivarri, "El Partido en su laberinto. La Federación Socialista Tucumana, 1931-1937" en Historia Regional, Sección Historia, ISP N³, Año XXI, № 26, 2008, pp. 137-164
} 
"feudos territoriales y electorales" que estaban cooptados por los capitalistas. ${ }^{64}$ Por eso, a partir de allí, en alianza con los sindicatos afines, algunos trabajadores vinculados al comunismo y el mismo PC, comenzaron a forjar acuerdos con los radicales apuntando a consolidar una suerte de "inserción democrática" ${ }^{65}$ o de "integración política." ${ }^{66}$ En la misma línea fueron acompañados también por el sindicato de trabajadores de la industria azucarera, el sindicato de Sastres, de la Construcción entre otros.

El Comité Regional del PC hizo un llamado a votar a la UCR en las elecciones de 1937, especificando a quién debían votar en cada localidad. Un tiempo después miembros del propio Comité Regional entablaron conversaciones con la Mesa directiva de la UCR donde se le garantizó la libre propaganda en un escenario de amenaza de "represión al comunismo" en todo el país. Asimismo, se discutieron estrategias para "evitar el triunfo de la Concordancia" que englobaba al PDN y a otros partidos conservadores ${ }^{67}$

Los dirigentes del sindicato azucarero basaron su apoyo en "el deseo unánime de unión para salvar los intereses de la clase trabajadora que han estado amenazados de sufrir un rudo golpe en las conquistas hechas hasta el presente bajo los gobernantes radicales que tuvo Tucumán." ${ }^{68}$ En tanto, los dirigentes del comunismo y los del socialismo obrero y sus sindicatos simpatizantes, justificaron su incursión política señalando que no era "una cuestión meramente electoralista, sino que se trata de un paso más de la clase trabajadora para asegurar su bienestar." 69

Empezaban entonces a aparecer muy claras dos cosas en el escenario obrero. En primer lugar el valor del voto como herramienta de transformación, y, en segundo lugar, el temor a un triunfo conservador que ponga en peligro las conquistas que ellos consideraban fundamentales. Por eso esgrimían que el principal motivo para la participación electoral era "afianzar la democracia y los derechos cívicos y sociales impidiendo que las minorías reaccionarias [...] obtengan algunas bancas." ${ }^{, 70}$ En 1938 el Partido Socialista Obrero lanzó un comunicado señalando que apoyaba la unión del radicalismo y llamando a todos los partidos democráticos y obrero a hacer lo mismo "ante la posibilidad que a causa de la

\footnotetext{
64 "Valores del movimiento obrero", en Izquierda, Año 1, Número 2, Noviembre de 1934

${ }^{65}$ Nicolás Iñigo Carrera, La estrategia de la clase obrera, 1936, Buenos Aires, Ed. Madres de Plaza de Mayo, 2004 y Nicolás Iñigo Carrera, "Formas de lucha de la clase obrera y organizaciones políticas en la Argentina de los años '30", Documento de trabajo PIMSA, Año II, No 2, 1998.

${ }^{66}$ Juan Carlos Torre, “¿Por qué no existió un fuerte movimiento obrero socialista en la Argentina?”, en Entrepasados, № 35, 2009, pp. 151-163

${ }^{67}$ Las negociaciones resultaron de alguna manera efectivas, ya que el gobierno de la provincia se negó sistemáticamente a aplicar una política represiva contra el PC que sí regía en provincias como Buenos AiresLa Gaceta, 20/02/1937. A fines de 1934 el ministro del Interior Leopoldo Melo apoyó una campaña de "localización de soviets" que fue minimizada en la provincia. Posteriormente, en 1936 lo sectores conservadores intentaron dar sanción al proyecto de ley de represión al comunismo en la provincia que fue postergado y finalmente no se sancionó. La existencia de ese proyecto en la Legislatura provincial, que iba acompañado de otro de enseñanza religiosa en las escuelas, provocó un intenso debate público sobre la libertad de opinión y de culto, del que participaron amplios sectores de la sociedad.

${ }^{68}$ La Gaceta, 22/10/1938

${ }^{69}$ La Gaceta, 04/03/1939 y El Orden, 01/03/1939.

${ }^{70}$ El Orden, 01/03/1939.
} 
división actual del radicalismo, triunfen las fuerzas conservadoras, y se terminen las garantías de que hoy disfruta la clase trabajadora en la provincia",71

Este miedo potenció su contracara, la necesidad de defender lo ganado. Esencialmente, las alocuciones de los dirigentes dilucidaban que esta construcción política que aspiraba a insertar a un sector de los trabajadores en el juego democrático estaba teñida del clima de época, donde el avance "reaccionario" se esbozaba muy tangente. En esa dirección, un tiempo después participaron en elecciones legislativas y a principios de 1939 fundaron una organización que se llamó Alianza Obrera y Democrática, desde donde "apoyarían desde la Legislatura el programa del actual gobernador en lo que respecta al mejoramiento de los obreros de la provincia.",72

Pero estas construcciones políticas tuvieron más dificultades que éxitos, ya que la disputa por la prescindencia, que todavía seguía flotando sobre el mundo obrero, bañaba la construcción de vínculos políticos extra sindicales. Otros partidos obreros como el Socialista y los trabajadores que los acompañaban se mostraron renuentes a participar de las campañas que impulsaban candidaturas radicales. Mucho menos si eran encabezadas por los comunistas. A pesar de ello, la Alianza fue a las elecciones municipales y obtuvo 575 votos, mejorando sensiblemente el número de votos que el PC había sacado en sus primeras elecciones. El PS obtuvo 817 y quedó muy lejos de los 10.117 que acusó la UCR.

En paralelo, parte del trabajo destacado de la alianza entre los sindicatos vinculados al PC y los vinculados al PSO fue cooptar la central provincial e instalar el debate sobre la política en $1939 .{ }^{73}$ Desde allí alimentaron esa línea-idea que fue central en la construcción de una estrategia de acción política: la del temor -no sin razones- respecto a la posibilidad de que la provincia, gobernada por radicales, fuera intervenida por el vicepresidente conservador, a cargo del Poder Ejecutivo, Ramón Castillo. En el discurso obrero, la lucha contra el capitalismo comenzó a complementarse con la lucha contra "la reacción", porque en definitiva eran dos caras de la misma moneda. Así explicaban que "mientras las fuerzas de la oligarquía continúen usufructuando ilegalmente el poder, la era de la violencia contra la soberanía popular no terminará." ${ }^{, 74}$ La única solución para el avance reaccionario, decían,

\footnotetext{
${ }^{71}$ La Gaceta, 05/08/1938

${ }^{72}$ La Gaceta, 04/03/1939 y El Orden, 01/03/1939. José Aricó, "Los comunistas y el movimiento obrero", en La Ciudad Futura, No 4, marzo de 1987 y Hernán Camarero, A la conquista de la clase obrera. Los comunistas y el mundo del trabajo en la Argentina, 1920-1935, Buenos Aires, Siglo XXI, 2007. La política de Alianzas Democráticas era común en esa época en varios países donde militantes del PC se incorporaron a estas estructuras en el marco de las políticas de "frente popular". En ese sentido, la vuelta de timón del Comintern, lanzado a la búsqueda de nuevas solidaridades extra obreras tras el abandono de la estrategia de "clase contra clase" a mediados de los treinta, dio un impulso crucial a la conformación de coaliciones y frentes. En esa coyuntura, alentó a los sindicatos con afinidad comunista a constituir alianzas locales con un amplio abanico de opciones políticas, incluso aquellas con profundo arraigo liberal como la UCR. Mucho más reticentes eran, en cambio, los socialistas, quienes seguían bregando por mantenerse al margen de cualquier alianza.

${ }^{73}$ María Ullivarri, Del sindicato a la central obrera en una trayectoria de provincia: Tucumán en los años 30", en Archivos de historia del movimiento obrero y la izquierda, Año II, N 4, marzo 2014, Buenos Aires, pp. 123-143.

${ }^{74}$ La Gaceta, 16/12/1940.
} 
era la participación de la clase obrera, ya que evaluaban que "la reacción consuma(ba) sus planes por la falta de unidad de los sectores democráticos y obreros". ${ }^{7}$

\section{Lo político como estructura}

Con el cambio de década, la situación política nacional estaba volviéndose más compleja, especialmente tras la licencia y posterior renuncia del presidente Ortiz. Su sucesor Ramón Castillo estructuró su mandato en la persecución al mundo sindical. Pero justamente cuando el malestar político comenzó a acelerarse, los grupos más politizados ya estaban instalados en la dirección de la central y articulados políticamente con grupos radicales en la provincia. Las opciones prescindentes, a esa altura, parecían ir desvaneciéndose. Lo electoral había permitido a los trabajadores vinculados a los partidos obreros consolidar alianzas a un nivel más amplio y también participar de la política burguesa aunque con resquemores. Pero la consolidación de una agenda de preocupaciones obrera era fundamental y para ello debían plantearse una nueva estrategia, más territorial y más confrontativa.

El primer esbozo concreto de lucha política popular realizado por los trabajadores organizados en sindicatos fue un llamado "a las fuerzas democráticas para que se unifiquen, organizándose en comités de barrio." 76 En esos espacios barriales, desde mitines organizados en las equinas, comenzó a discutirse sobre la carestía de la vida, los avatares de la guerra, los bajos jornales, el problema de las inundaciones de los barrios del sur, la necesidad de defender la democracia y de garantizar la unión de las fuerzas democráticas. Los trabajadores construían su agenda política, popular y propia y al mismo tiempo utilizaban esos espacios también para informar sobre la situación de huelgas o conflictos llevados adelante por algún sindicato de la ciudad o la campaña. Posteriormente se fue sumando el tema de la reducción de las libertades públicas. Los trabajadores se quejaban, "nos aplicaron el estado de sitio hace más de un año [...]no podemos hacer una reunión en nuestra sociedad sin que se hagan presente de inmediato policías, taquígrafos, etc.",77

En esa dirección, la constante prohibición del derecho de reunión en plazas y calles y los reiterados intentos de limitar la libertad de expresión a través de decretos que prohibían el tratamiento de temas vinculados a la neutralidad fueron profundizando la agenda de preocupaciones. ${ }^{78} \mathrm{La}$ policía se encargó de aclarar que, debido al "estado especial provocado por el conflicto bélico de Europa", estaba obligada "a determinar limitaciones", porque "encauzar y mantener en los márgenes de la normalidad a las corrientes populares constituye uno de los deberes imprescriptibles de poder de policía."79

La cuestión de la neutralidad estaba tensando las relaciones políticas en el país, mientras que la demanda de democracia y la lucha contra fascismo se convertían en tópicos de unidad y comenzaron a volverse matrices fértiles para proponer discusiones, instalar

\footnotetext{
${ }^{75}$ La Gaceta, 16/12/1940.

${ }^{76}$ La Gaceta, 08/01/1941.

${ }^{77}$ Reportaje al obrero pintor Lorenzo Durand, La Unión, 02/12/1942.

${ }^{78}$ La Gaceta, 12/08/1940, 15/01/1942, 30/04/1942, 26/02/1943; La Unión, 03/09/1942, 28/04/1943.

${ }^{79}$ La Unión, 30/4/1942.
} 
agendas, construir internamente y leer la clave política nacional. Algunos lo hicieron a través de sus sindicatos, como el Sindicato de Resistencia de Obreros Sastres que conformó un "Comité Obrero Antinazi" para proponer acciones e informar a la población. ${ }^{80}$ Otros trabajadores buscaron diferentes espacios de inserción como la organización Acción Argentina que extendió filiales por casi toda la provincia. ${ }^{81} \mathrm{O}$ se vincularon a través de sus partidos o sus sindicatos con la conformación de la Alianza Democrática ${ }^{82}$ o con la Junta Coordinadora de Acción Democrática, de la que participaron radicales y comunistas.

El movimiento asociacionista fue intenso y fue articulando a los sindicatos y trabajadores con otros espacios políticos con presencia en la provincia. De hecho la prensa se sorprendió de que llegó incluso a "limar asperezas entre los partidos políticos". ${ }^{83}$ Sin embargo, a pesar de que la movilización popular tuvo como uno de los pilares más importantes el llamado a votar al radicalismo, a principios de 1942 los radicales perdieron las elecciones por primera vez desde 1917. En ese momento, la certeza que venía construyéndose respecto al avance conservador y la amenaza al sistema democrático se materializó con pruebas concretas.

La provincia gobernada por radicales había logrado sortear las políticas represivas y de fraude que los gobiernos conservadores habían impuesto en la mayor parte del país. En ese contexto, la muerte del presidente Ortiz en julio de 1942 fue un punto de inflexión. El anhelo de su vuelta y las posibilidades de revertir el estado de cosas se desvaneció y comenzó a volverse más perceptible una insistente campaña de rumores sobre la inminencia de una intervención federal a la provincia. A partir de allí los dirigentes y los trabajadores salieron de sus trincheras dispuestos a dar una batalla política concreta. El comunismo buscó diferentes alianzas en procura de mejores resultados electorales. ${ }^{84}$ Por su parte, los dirigentes obreros fundaron una organización que llamaron "Unión Obrera y Democrática" para apoyar la candidatura del radical Miguel Campero, cuya sede estaba localizada en el local del Sindicato Único de Obreros de la Construcción.

La energía invertida en el trabajo electoral, sin embargo, no alcanzó para garantizar una amplia mayoría y luego de un virtual empate entre demócratas y radicales, los conflictos en el Colegio Electoral impulsaron su intervención y, un tiempo después, ya

\footnotetext{
${ }^{80}$ La Gaceta, 10/12/1941.

${ }^{81}$ La primera sección de Acción Argentina se fundó en 1940 en Aguilares y funcionaba en el Centro de Socorros Mutuos. Nueve meses después ya había ramas en La Cocha, Villa Alberdi, Famaillá, Lules, Concepción, La Trinidad, Medinas y Monteros. De ella participaron mayormente comerciantes, profesionales y también trabajadores como, por ejemplo, algunos dirigentes de la Unión General de Trabajadores de la Industria Azucarera, sindicato que agrupaba a los obreros del azúcar. Andrés Bisso, Andrés, Acción Argentina. Un antifascismo nacional en tiempos de guerra mundial, Buenos Aires, Prometeo, 2005.

${ }^{82}$ De esa Alianza participaban miembros de la UCR Frente Popular, del Partido Socialista, de la Sociedad de Empleados y Obreros de Comercio, de la Sociedad de Resistencia de Obreros Panaderos, del Sindicato de la Construcción, de la Unión Chauffeurs y también dirigentes agrarios. La Gaceta, 14/08/1941. Los propósitos de esta organización eran "orientar al pueblo hacia la fe democrática y luchar por la reafirmación de los principios institucionales y por la depuración de los mismos."

${ }^{83}$ La Gaceta, 28/09/1941.

${ }^{84}$ El PC apoyó las candidaturas de la UCR Frente Popular con muy pobres resultados, mientras que el PS abandonó su rechazo a las alianzas y se vinculó con el Partido Agrario de Famaillá, obteniendo una elección récord en ese departamento, quintuplicando sus votos.
} 
vencido el mandato del gobernador en funciones, la provincia fue intervenida completamente. $^{85}$

El período que transcurrió entre la intervención del colegio electoral y la intervención federal de la provincia es sumamente rico en acontecimientos políticos. En ese espacio de transición e incertidumbre, los días avanzaban hacia el vencimiento del mandato del gobernador $\mathrm{y}$, sin gobernador electo la intervención se volvía inevitable. Allí los trabajadores aprovecharon para profundizar su influencia en el gobierno. La representación local de la CGT, llamada Comisión Cooperadora, se había fundado de la mano de los socialistas y, apelando a su tradición, se había mantenido al margen de las disputas domésticas. Sin embargo, la gravedad de la situación política la impulsó a organizar un acto para repudiar "el avallasamiento de las autonomías provinciales." ${ }^{86} \mathrm{Y}$ desde las tribunas llamaron a los trabajadores a involucrarse en los asuntos políticos. La Comisión Cooperadora -decía el comunicado- "entiende que los hombres libres no pueden ser indiferentes a las pretensiones de sectores reaccionarios que en la Nación accionan vilmente para imponer un régimen de opresión que anule la libertad y el imperio del derecho." ${ }^{87}$

Un renovado discurso cegetista fue marcando una nueva pauta en la politización obrera. En el acto habló el Secretario General, el socialista Doroteo Lescano quien indicó que para consolidar esa democracia con reivindicación social "había llegado la hora de escuchar a la clase obrera y de consultarla en los actos de gobierno." ${ }^{88}$ Esta situación forzosamente ampliaba los márgenes de la lucha y, como lo señaló el dirigente ferroviario Emilio López, extendía las responsabilidades sociales de la clase obrera que "al mismo tiempo que debe defender sus conquistas y resolver sus propios problemas, debe tener presente que ahora se le plantea el problema de la libertad." ${ }^{89}$ La situación de los trabajadores había cambiado mucho- "La militancia sindical", decía un comunicado de la seccional local de La Fraternidad, era el "puntal con el que cuentan los gobiernos para proteger las instituciones republicanas." 90

\section{"El pueblo políticamente organizado"}

Luego de la embestida del Poder Ejecutivo, la intervención federal abrió las posibilidades para una nueva elección provincial. El arco político parecía no poder articular

\footnotetext{
${ }^{85}$ Hasta la reforma constitucional de 1990, las elecciones a gobernador en Tucumán fueron indirectas. En las elecciones para gobernador de octubre de 1942 se generó un escenario de "paridad" entre el Partido Demócrata Nacional (PDN) y la UCR de Miguel Campero. Ante el empate en el número de electores, la tercera fuerza, la UCR dirigida por Roque Raúl Aragón, debía ser la encargada de desempatar la disputa. Las dificultades para llegar a un acuerdo suscitaron una gran inestabilidad política, el Poder Ejecutivo Nacional tomó la decisión de enviar una misión federal a la provincia para intervenir el Colegio Electoral y garantizar "la forma republicana de gobierno." La Unión, 27/11/1942

${ }^{86}$ Del acto participaron 2500 personas, y adhirieron todas las ramas de la UCR, el PS, el PC, la Federación Universitaria, los gremios autónomos y la CGT. La Gaceta, 02/12/1942.

${ }^{87}$ La Unión, 29/11/1942.

${ }^{88}$ La Unión, 06/12/1942.

${ }^{89}$ Discurso de Emilio López, reproducido en La Gaceta, 01/05/1942.

${ }^{90}$ La Gaceta, 10/11/1942.
} 
una respuesta y en esa dirección, los trabajadores entendieron que la posibilidad de conseguir mejores resultados electorales, pensando fundamentalmente en las elecciones nacionales, pero también en las locales, dependía de la capacidad de movilizar apoyos. Sin "los titubeos y las vacilaciones tan frecuentes en el resto del arco opositor," ${ }^{91}$ los miembros de los sindicatos de la construcción y de la madera se adelantaron y fundaron en la sede del Sindicato Obrero de la Construcción, un "Comité Democrático Organizador Pro Unidad Democrática". Con esa oportunidad podían por fin dar forma a su idea de construcción política. En un manifiesto los trabajadores explicaron que "El comité organizador "Pro Unidad Nacional" [...] no pretende suplantar ni estorbar la acción de las autoridades y de los partidos políticos y organizaciones obreras y estudiantiles, sino colaborar con ellas y secundar su acción.[...] Hay un puesto de lucha y de trabajo para todos y para cada uno. Ni hacemos exclusiones ni pretendemos exclusividad en la tarea grande de devolver la soberanía a la patria y la ciudadanía a los argentinos. ${ }^{92}$

La iniciativa, tal como la habían planteado los fundadores del Comité Organizador, iba más allá de las estructuras orgánicas y apuntaba a un cambio más profundo a nivel social. Al respecto Pedro Suárez, dirigente del Sindicato de la Construcción, explicaba que el motor para conformar la unidad era el "pueblo políticamente organizado" y había que luchar "por unirse sobre las banderías políticas" porque así "solo interesa lo que cada uno puede dar. $" 93$ La propuesta era la movilización territorial apelando a cooptar instituciones de la vida local: juntas vecinales, centros de jubilados, de comerciantes, ateneos y bibliotecas populares, comisiones de amas de casa, centros barriales, etc. Asimismo, a través de estas organizaciones la idea era también extender capilarmente el movimiento a través de comisiones en los barrios y pueblos del interior con el propósito de "formar cien comités en la provincia que brinden apoyo a los partidos que se pronuncien por la unidad" con la idea de organizar políticamente a la sociedad para garantizar la ciudadanía. ${ }^{94}$

El plan de acción desarrollado por los obreros apuntaba a crear una "sociedad política" y su táctica reproducía la particular manera de articular la militancia con la política que tenía el PC, pero también abrevaba en los espacios que el radicalismo había ido construyendo en los pueblos y en los barrios, comités y centros. ${ }^{95}$ El resultado fue casi inmediato y al poco tiempo comenzaron a surgir los Comités Pro Unidad por los barrios y las ciudades del interior. ${ }^{96}$ Sus planes de trabajo cubrían un vasto campo de problemas:

\footnotetext{
${ }^{91}$ Tulio Halperin Donghi, La República imposible, 1930-1945, Buenos Aires, Ariel, 2004, 280.

${ }^{92}$ Manifiesto del Comité Pro Unidad Nacional, reproducido en La Unión, 06/02/1943.

${ }^{93}$ La Unión, 12/01/1943.

${ }^{94}$ La Unión, 23/03/1943; La Gaceta, 14/01/1943.

${ }^{95}$ Omar Acha, "Sociedad civil y sociedad política durante el primer peronismo", Desarrollo Económico, Volumen 44. Número 174. 2004 pp. 199-230

${ }^{96}$ Los Comités formados fueron La Ciudadela, Sindicato de la Construcción, Movimiento Pro Unidad de la Juventud, Villa Luján, Villa 9 de Julio, Villa Quilmes, Comité de Unidad Nacional Lisandro de la Torre, Comité de Unidad Nacional Enzo Bordabehere, Comité de Unidad Nacional Mariano Moreno, todos en la ciudad capital. En el resto de la provincia se fundaron en Monteros, Villa Alberdi, Lules, El Manantial, Villa Colmenar y, en Tafí Viejo, el Comité de Unidad Nacional del Personal del Ferrocarril Central Argentino.En Villa Alberdi se conformó a partir de la sección local de Acción Argentina, mientras que, por ejemplo, el Movimiento Pro Unidad de la Juventud agrupaba a las ramas juveniles de la UCR, el PC, el PS y la FUT.
} 
defender la autonomía de la provincia; protestar por el embargo a las rentas municipales; el problema de la carestía de la vida, los pedidos de aumento de salarios, la especulación, el maltrato a los trabajadores, el problema de la escasez de nafta, la asistencia médica gratuita, la posibilidad de un futuro decoroso para la juventud a través de la creación de escuelas de artes y oficios, gimnasios, etc. ${ }^{97}$ En ese sentido, ninguno agotaba su prédica solo en el problema de la Unidad, sino que canalizaban y reproducían las demandas circulantes.

A través de actos y reuniones las ideas y discusiones se iban logrando "la agitación de las masas [...] a favor de la unidad." ${ }^{98}$ En los diarios de la época se reflejaba parte de esta politización. En las columnas de opinión y en las cartas los ciudadanos de la provincia expresaban anhelos y esperanzas, la mayoría de los cuales estaban vinculados con la política. Los dirigentes obreros, como Manuel Espinosa, del sindicato de la construcción, verbalizaban en los actos los deseos de que la clase obrera se involucre políticamente "y dónde mejor que en la Unidad Nacional.” En tal sentido, el mismo dirigente también habló de la trayectoria del movimiento obrero en pos del abandono de "la teoría anodina del apoliticismo" entendiendo que "en momentos tan graves como el actual los trabajadores tienen una excelente oportunidad de lograr sus reivindicaciones por medio de la lucha política." 99

Luego de la intervención total de la provincia, la lucha política se vio dificultada, fundamentalmente porque una de las primeras medidas del gobierno fue prohibir las actividades del PC y de todo aquello que era sospechoso de estar vinculado al comunismo. Al compás, se profundizaron las restricciones a la actividad sindical y se prohibió la acción al Partido Comunista. Esta "Campaña de profilaxis" dejó sin margen de acción a los sindicatos, porque "los organismos colocados al margen de la ley no contarán con campo propicio a sus actividades subversivas." 100 Pero esos "extremistas" se habían mezclado en las organizaciones que habían generado, en los comités $\mathrm{y}$, fundamentalmente, en la Comisión Organizadora de la Unidad Democrática.

En ese sentido, fuera del espacio sindical que estaba siendo exageradamente vigilado, las reglas eran más flexibles y podían encontrarse nichos para actuar. Allí, en el marco de la organización política con miras a las elecciones, los comités de unidad absorbieron el trabajo gremial a través de la presentación de denuncias por incumplimiento de leyes obreras, malos tratos, presentación de habeas corpus para los detenidos, etc. La situación, sin dudas, era compleja.

El estado de sitio declarado por Castillo, la incertidumbre política de la provincia y la irresolución en la que naufragaban las discusiones en torno a las candidaturas de la Unión Democrática tanto a nivel nacional como provincial, desdibujaban el rumbo que iba tomando la iniciativa política de los trabajadores en la provincia. Sin embargo, algo si estaba claro, la prescindencia política que había sido una bandera sindical durante muchos años, en 1943 ya no tenía margen para discutirse en la provincia. En el acto del $1^{\circ}$ de mayo los oradores reclamaron explícitamente la participación política de la clase trabajadora.

\footnotetext{
${ }^{97}$ La Unión, 09/02/1943 y La Gaceta, 12/01/1943, La Unión, 25/01/1943.

${ }^{98}$ Discurso de Lisandro Caballero del Comité Organizador Pro Unidad, La Gaceta, 15/02/1943.

${ }^{99}$ La Unión, 15/02/1943.

${ }^{100}$ La Gaceta, 20/02/1943.
} 
Manuel Fernández, dirigente del Sindicato del Vestido contó la historia que todos conocían y le dio un final distinto "Hasta el presente las organizaciones sindicales se habían mantenido prescindentes en las luchas políticas. Se preocuparon por las luchas sociales y por cuando afectaba directamente a los intereses económicos y de clase de los trabajadores organizados. Los acontecimientos del mundo han demostrado la equivocación que implicaba esta táctica de lucha. La clase obrera, bregando por sus propios intereses, está obligada a participar en forma activa en la contienda política y en el acondicionamiento de las candidaturas." 101

Sin dudas la trayectoria política de los trabajadores tucumanos se volvía cada vez más intensa, porque en las particulares e impredecibles circunstancias de principios de la década del cuarenta, terminó de cuajar la certeza de que si antes habían existido posibilidades de plantear una lucha exitosa exclusivamente obrera y circunscripta a lo económico, en ese momento histórico ya no existían. En efecto, en la estratégica búsqueda de soluciones a sus problemas, los dirigentes gremiales llevaron al movimiento sindical tucumano por nuevos espacios de intercambio que lo fortalecieron al insertarlo socialmente y al conjugar sus intereses con los de otros grupos. Por eso, la asociación de organizaciones de clase como la CGT y los sindicatos tucumanos con otros sectores sociales y partidos politicos, tuvo el acento político de un clima de época que exigía forjar alianzas y solidaridades. En los últimos y conflictivos meses de la "Restauración Conservadora" se consolidó una suerte de "ethos colectivo", destinado a garantizar la subsistencia de algo que antes parecía ajeno al mundo obrero como la democracia.

\section{Cierre}

En un escenario donde dirigentes de partidos de izquierda y dirigentes sindicales eran casi las mismas personas, las disputas por la prescindencia revelaban parte de las tensiones por el poder en el acotado mundo gremial de una provincia argentina. Tanto los militantes vinculados al PC, como los que lo estaban con el PS atravesaron el período discutiendo las "formas correctas" de ser obrero y la necesidad o no de la participación política. Sin embargo, por fuera de ahí la voluntad política de los trabajadores era amplia e involucraba un fructífero vínculo con el gobierno y con las instituciones hacia arriba, mientras que hacia abajo se fue volcando en comités y estructuras territoriales que, no obstante, estaban, la mayoría de ellas, sostenidas por los partidos de izquierda y se reproducían a través de esos partidos.

Para un importante número de dirigentes obreros el nuevo escenario propuesto por la Ley Sáenz Peña no transformaba de cuajo las cosas, pero si modificaba las posibilidades de disputar poder, porque como señalaba La Protesta "la clase trabajadora no es neutral frente al Estado." 102 De esta forma, entendemos que las prácticas de resistencia también funcionaron en consonancia con las negociaciones, entendiendo esto como una "pragmática vitalista." 103 Así, en espacios donde las relaciones de fuerza eran desventajosas, la

\footnotetext{
${ }^{101}$ La Gaceta, 03/05/1943.

${ }^{102}$ La Protesta, 03/09/1929

${ }^{103}$ Parta Chattarjee, La nación en tiempo heterogéneo, Buenos Aires, Siglo XXI, 2008
} 
búsqueda de oportunidades hacía más compleja la relación nunca prolija entre discurso y práctica.

La prescindencia fue entonces una postura sindical que pretendía resguardar un status quo en defensa de lo que supuestamente habían conquistado, pero esa defensa, para otros grupos, también estaba vinculada a la necesidad de participación política. Esa tensión difícil de resolver pivoteaba fuerte, perfilando el discurso prescindente y provocando caminos de unión y desunión entre los diferentes grupos actuantes en la provincia. Así, los esfuerzos de un sector por consolidar una clase obrera independiente se enfrentaban a una realidad donde los trabajadores iban forjando estrechos vínculos políticos con el gobierno y arrastraban a parte del movimiento sindical tucumano hacia la construcción de una estrategia para gestionar su incorporación al mapa político. Las formas de lograr esa inserción fueron diversas, fallidas algunas y otras más exitosas. La construcción de alianzas multisectoriales, el trabajo electoral, las solidaridades extraobreras, el apoyó a los candidatos de la UCR, etc. Pero, por otro lado, también buscaron participar electoralmente acompañando partidos obreros en elecciones municipales. De ese proceso dan cuenta el "Comité Pro Defensa de la Democracia", "la Alianza Obrera y Democrática", la "Alianza Democrática", la "Unión Obrera y Democrática" y el "Comité Democrático Pro Organizador de la Unión Democrática."

A medida que se consolidaba esta vertiginosa dinámica asociativa se fue tiñendo con un sentido mayor, la "defensa de la democracia." Aunque esta idea estuvo ajena al mundo obrero durante sus primeros años de funcionamiento en el país, fue arraigando como significado de lucha y definiéndose "por su resistencia a transar con cualquier método o sistema que conduzca o implique aquello que la democracia combate." ${ }^{104}$ Esa misma operación de resignificación constante envolvía diversas representaciones colectivas y habilitaba, por tal motivo, múltiples pautas para la acción política. En un contexto mundial donde la apasionada disputa entre "la libertad" y "la reacción" articulaba el pulso de la política, no es extraño que los dirigentes sindicales tucumanos, buscando un espacio de inserción, se alimentaran de ese lenguaje -adquirido a través del conflicto que dividía el mundo en dos bloques irreconciliables- y que con él leyeran la clave política nacional y su contexto político más inmediato.

Durante los años de la entreguerras, el complejo intermitente y reticular de organizaciones, partidos y sindicatos configuró un escenario político popular muy dinámico. Esa presencia barrial, en las fábricas y en los pueblos de las alocuciones democráticas y de la necesidad de la unidad fue desaprovechada por los partidos políticos que buscaban consensuar posturas y por la misma CGT, que se encontró tironeada entre los mandatos nacionales de prescindencia y las demandas locales. Su consigna, la defensa de la democracia, no pudo establecerse a partir de una alianza política, pero su movilización garantizó la consolidación de ésta a través de su disputa en las calles.

La clase obrera tucumana, o sus dirigentes, frente a la complejidad que revestía el universo en el que ellos se movían y abrazados a una profunda incertidumbre sobre el futuro, fueron tejiendo un paño de solidaridades, alianzas y apoyos para dar forma a un

\footnotetext{
${ }^{104}$ Mario Bravo, "UniónDemocrática Argentina”, en Argentina Libre, año 3, No 111, 07/05/1942, reproducido en Andrés Bisso,(Comp.), El antifascismo argentino, Buenos Aires, Buenos Libros/CeDInCI, 2007, p. 564.
} 
nuevo escenario sindical y político en la provincia. Este entramado de solidaridades tenía presencia continua en el espacio público y aspiraciones de inserción y legitimidad propia que, prontamente, le fueron otorgando un peso específico relevante como interlocutor obligado de partidos, gobiernos y grupos sociales y se sintieron, por ello, con derecho a discutir la Nación y su política.

La búsqueda de grietas en los sistemas normativos conforma parte fundamental de la estrategia de los grupos subalternos quienes, de esa forma imprimen su marca en la realidad política condicionando o modificando las formas de dominación. ${ }^{105}$ En efecto, la hegemonía constituye un proceso de institución de límites políticos y sociales y busca conformar espacios, y posibilidades, construyendo fundamentalmente "la imaginación política" de los sujetos. ${ }^{106}$ En ese sentido, Alejandro Grimson señala que la estructuración social y política comienza a agrietarse cuando la legitimidad del consenso empieza a ser disputada. En ese sentido, la disputa por un espacio político produjo un salto cualitativo en la lucha sindical y buscó conformar su propia imaginación política. Allí, en ese lugar por tanto tiempo ajeno a la clase obrera y tan negado por sus propios dirigentes, sus tensiones, sus inestabilidades, sus contradicciones, sus ambigüedades habían abierto un intersticio para que un puñado de trabajadores organizados se filtrara con notable entusiasmo. Esa voluntad no fue la de la mayoría, sino la de determinado grupo de trabajadores, principalmente vinculados a los partidos políticos convencidos que "el pueblo políticamente organizado" era la respuesta para mejorar la situación de la clase obrera. El golpe de junio de 1943, desarticuló las estrategias previas de los dirigentes locales, pero habilitó nuevas posibilidades políticas. Esa, sin embargo, es otra historia.

La política que se territorializa estuvo estrechamente relacionada con un contexto internacional de disputa por la democracia, de un ámbito nacional de avance conservador y con un espacio local de gobiernos radicales que moldearon las trayectorias de los actores. Estas fueron las fronteras de sentido para la construcción política de los trabajadores y sus posibilidades de creación organizaron las prácticas obreras.

\section{Bibliografía}

Abad de Santillán, Diego, La F.O.R.A., Buenos Aires, Editorial Proyección, 1971.

Acha, Omar, "Sociedad civil y sociedad política durante el primer peronismo", Desarrollo Económico, Volumen 44. Número 174. 2004 pp. 199-230.

Aricó, José, "Los comunistas y el movimiento obrero", en La Ciudad Futura, No 4, marzo de 1987 Baily, Samuel, Movimiento obrero, nacionalismo y política en la Argentina, Buenos Aires, Hyspamérica, 1985.

Barrancos, Dora, Anarquismo, educación y costumbres en la Argentina de principios de siglo, Ed. Contrapunto, Buenos Aires, 1990.

\footnotetext{
${ }^{105}$ Giovanni Levi, La herencia inmaterial. La historia de un exorcista piamontés del siglo XVIII, Madrid, Nerea, 1990, p. 11.

${ }^{106}$ Alejandro Grimson, (Comp), Cultura y Neoliberalismo, Buenos Aires, CLACSO, 2007
} 
Bertoni, Ana y De Privitellio, Luciano, "Introducción", en: Lilia Ana Bertoni y Luciano de Privitellio (eds.), Conflictos en democracia. La vida política argentina entre dos siglos, Buenos Aires, Siglo XXI, 2009.

Bilsky,Edgardo, "Campo político y representaciones sociales: estudio sobre el sindicalismo revolucionario en la Argentina (1904-1910)", Paris, Mimeo, 1988.

Bisso, Andrés, (Comp.), El antifascismo argentino, Buenos Aires, Buenos Libros/CeDInCI, 2007.

Bisso, Andrés, Acción Argentina. Un antifascismo nacional en tiempos de guerra mundial, Buenos Aires, Prometeo, 2005.

Bravo, María Celia, "El populismo radical en Tucumán en la década de 1920: conflictos azucareros y crisis política", en Alfredo Bolsi (Comp.), El complejo azucarero en Tucumán. Dinámica y articulaciones. UNT, Versión CD Rom, 2002.

Camarero, Hernán, "La izquierda partidaria y la CGT, 1935-1939. Las disputas entre el frentpopulismo comunista y la prescindencia apolítica de la dirección sindicalista" en Actas de las XIII Jornadas Interescuelas/Departamentos de Historia, Catamarca, agosto, 2011.

Camarero, Hernán, "La experiencia comunista en el mundo de los trabajadores, 1925-1935", Prismas, $\mathrm{N}^{\circ}$ 6, Quilmes, 2002,

Centurión, Josefina, "Cultura y Sociabilidad en los Pueblos Azucareros", Tesina de Licenciatura, Universidad Nacional de Tucumán, 2000, 100

Chattarjee, Parta, La nación en tiempo heterogéneo, Buenos Aires, Siglo XXI, 2008

De Privitellio, Luciano, Vecinos y ciudadanos. Política y sociedad en la Buenos Aires de entreguerras, Siglo XXI, Buenos Aires, 2003

Del Campo, Hugo, Sindicalismo y Peronismo. Los Comienzos de un Vínculo Perdurable, Buenos Aires, Siglo XXI, 2005, (Primera edición de 1983);

Devoto, Fernando, "De nuevo el acontecimiento: Roque Sáenz Peña, la reforma electoral y el momento político de 1912" en Boletín del Instituto de Historia Argentina y Americana Dr. Emilio Ravignani, número 14, segundo semestre de 1996.

Doyon, Louise, Perón y los trabajadores, Buenos Aires, Siglo XXI, 2006.

Durruty, Celia, Clase Obrera y Peronismo, Buenos Aires, Pasado y Presente, 1969.

Falcón, Ricardo y Monserrat, Ana, "Estado, empresas, trabajadores y sindicatos", en R. Falcón (dir.), Nueva Historia Argentina, Democracia, conflicto social y renovación de ideas (1916-1930), t. 6, Buenos Aires, Sudamericana, 2000;

Falcón, Ricardo, "La relación Estado-sindicatos en la política laboral del primer gobierno de Yrigoyen", en Estudios Sociales, No 10, a. VI, $1^{\circ}$ semestre de 1996;

Falcón, Ricardo, "Política laboral y relaciones Estado-sindicatos en el gobierno de Hipólito Yrigoyen (1916-1922), en Juan Suriano (Comp.), La cuestión social en Argentina 1870-1943,

Buenos Aires, La Colmena, 2000

Ferrari, Marcela, Los políticos en la república radical: prácticas políticas y construcción de poder (1916-1930), Buenos Aires, Siglo XXI, 2008;

García, Leandro, "Animarse a la prescindencia: La lógica de construcción político ideológico de la corriente sindicalista en la CGT (1930-1935)," Tesis de Maestría, Universidad Nacional de La Plata. Facultad de Humanidades y Ciencias de la Educación, 2013.

Gayol, Sanda, Melon, Julio y Roig, Mabel, "Peronismo en Tandil ¿Perpetuación conservadora, desprendimiento radical o génesis sindical? 1943-1948”, en Anuario IEHS, N 3, Tandil, 1988.

González, Matías, "Distintas medidas y relación gobierno-clases trabajadoras durante el gobierno de Bascary. 1917-1919”, Documento de Trabajo, CAE, Tucumán, s/f, Inédito.

González, Matías, "La construcción de las identidades políticas en Tucumán: lógicas populistas: 1916-1934", en Actas de las I Jornadas de Jóvenes Investigadores, UNT-AUGM, Tucumán, Junio 2007 
Grimson, Alejandro et al, La vida política en los barrios populares de Buenos Aires, Buenos Aires, Prometeo, 2009.

Grimson, Alejandro, (Comp), Cultura y Neoliberalismo, Buenos Aires, CLACSO, 2007

Gutiérrez, Leandro y Romero, Luis Alberto, Sectores populares, cultura y política. Buenos Aires en la entreguerras, Buenos Aires, Siglo XXI, 2007.

Halperin Donghi, Tulio, La República imposible, 1930-1945, Buenos Aires, Ariel, 2004, 280.

Halperin Donghi, Tulio, Vida y muerte de la república verdadera, 1910-1930, Buenos Aires, Ariel, 2000;

Horowitz, Joel, "Patrones y clientes: el empleo municipal en el Buenos Aires de los primeros gobiernos radicales (1916-1930)", en Desarrollo Económico, Vol. 46, No. 184, enero-marzo de 2007, pp. 569-596,

Iñigo Carrera, Nicolás, "Formas de lucha de la clase obrera y organizaciones políticas en la Argentina de los años '30", Documento de trabajo PIMSA, Año II, N² 2, 1998.

Iñigo Carrera, Nicolás, La estrategia de la clase obrera, 1936, Buenos Aires, Ed. Madres de Plaza de Mayo, 2004

Íscaro, Rubens, Historia del movimiento sindical, Buenos Aires, Ciencias del Hombre, 1973, tomo IV, 26.

Justo, Juan B., Obras Completas de Juan B. Justo, Buenos Aires, La Vanguardia, 1978.

Landaburu, Alejandra, "Los empresarios azucareros y la cuestión social. Tucumán 1916-1930", Tesis de Doctorado-Universidad Nacional de Tucumán, Tucumán, 2014.

Landaburu, Landaburu, "Estado, empresarios y obreros: los empresarios y el Departamento de Trabajo ante las huelgas de 1919 en Tucumán", en Actas de las XI Jornadas Interescuelas/Departamentos de Historia, Universidad Nacional de Tucumán, Tucumán, 2007;

Latour, Bruno, Reassembling the Social: An Introduction to Actor-Network-Theory, Oxford, Oxford University Press, 2005.

Levi, Giovanni, La herencia inmaterial. La historia de un exorcista piamontés del siglo XVIII, Madrid, Nerea, 1990, p. 11.

Lichtmajer, Leandro, "La UCR Tucumana frente al triunfo peronista. Centralización partidaria, declive de los comités y depuración en las prácticas políticas", en Pablo Pérez Bandra (comp.) Partidos y micropolítica, Buenos Aires, Ed. Suárez, 2011;

Lichtmajer, Leandro, "La UCR Tucumana frente al triunfo peronista. Centralización partidaria, declive de los comités y depuración de las prácticas políticas", en Pablo Pérez Branda (comp.) Partidos y Micropolítica, Ed. Suárez, Mar del Plata, 2011.

Lobato, Mirta, "Rojos. Algunas reflexiones sobre las relaciones entre los comunistas y el mundo del trabajo en la década de 1930", en Prismas, Quilmes, N 6, 2002;

Mackinnon, Moira, "El protagonismo del movimiento obrero tucumano en la formación del Partido Peronista (1945-1950)", en Sergio Grez Toso, Francisco Zapata y Moira Mackinnon, Formas tempranas de organización obrera, Documento de Trabajo $\mathrm{n}^{\circ} 4$, Instituto Di Tella, Buenos Aires, La Crujía, 2003.

Macor, Darío y Tcach, César (Ed.) La invención del peronismo en el interior del país, Santa Fe, UNL, 2003

Marotta, Sebastián, El movimiento sindical argentino, Buenos Aires, Ediciones Libera, 1975, tomo I.

Martínez, Ilana, "Conflictos, disidencia y radicalización. El ala de izquierda del Partido Socialista argentino, 1929-1937”, en Actas II Jornadas Nacionales de Historia Social, La Falda, 2009.

Matsushita, Hiroshi, Movimiento obrero argentino 1930-1945, Buenos Aires, Hyspamérica, 1983; Joel Horowitz, Joel, Los sindicatos, el Estado y el surgimiento de Perón, 1930-1946, Buenos Aires, Eduntref, 2004. 
Murmis, Miguel y Portantiero, Juan Carlos, Estudios sobre los orígenes del peronismo, Buenos Aires, Siglo XXI, 2004 (Primera edición en 1974)

Oddone, Jacinto, Gremialismo proletario argentino, Buenos Aires, La Vanguardia, p. 196

Ortiz Bergia, María José, De caridades y derechos. La construcción de políticas sociales en el interior argentino. Córdoba (1930-1943). Córdoba, CEH "Prof. Carlos S. A. Segreti", 2009,

Pasolini, Ricardo, "El nacimiento de una sensibilidad política. Cultura antifascista, comunismo y nación en Argentina: Entre la A.I.A.P.E. y el Congreso Argentino de la Cultura, 1935-1955”, en Desarrollo Económico, $n^{\circ}$ 179, Oct-Dic., 2005;

Pasolini, Ricardo, "El antifascismo como problema: perspectivas historiográficas y miradas locales”, en Boletín Bibliográfico Electrónico del Programa Buenos Aires de historia política, en http://historiapolitica.com/boletin, Año 1, $\mathrm{N}^{\circ}$ 2, septiembre de 2008,

Piliponsky, Esteban, “Autonomía y peronización. El sindicalismo tucumano (1943-1946)", Tesina de Licenciatura, Universidad Nacional de Tucumán, 2008.

Rock, David, "Machine politics in Buenos Aires and the argentine radical party, 1912- 1930", en Journal of Latin American Studies, Vol. 4, No. 2, noviembre de 1972, pp. 233-256

Rock, David, El Radicalismo argentino, 1890-1930, Buenos Aires, Amorrortu, 1977

Romero, Luis Alberto, "Madurez de la sociedad civil. 1920-1943", en Roberto Di Stefano, et al, De las cofradías a las organizaciones de la sociedad civil. Historia de la iniciativa asociativa en Argentina. 1776-1990, Buenos Aires, Edlab, 2002

Romero, Luis Alberto, "Sociedad democrática y política nacional y popular: la Argentina en la primera mitad del siglo XX", Estudios Sociales, 46, primer semestre de 2014, pp. 145-170.

Rosenzvaig, Eduardo, Tucumán, crisis de un modelo y modelo de una crisis, Tucumán, UNT, 1988; María Ullivarri, “Trabajadores, Estado y política en Tucumán, 1930-1943”, Tesis de Doctorado, Universidad de Buenos Aires, 2010;

Rubinstein, Gustavo, Los sindicatos azucareros en los orígenes del peronismo tucumano,Tucumán, Universidad Nacional de Tucumán, 2006.

Siviero, Fernando, "Trabajadores del sistema agro azucarero tucumano. Una visión desde el debate "trabajadores nuevos-trabajadores viejos", en Actas de las Jornadas Pre Congreso ASET, Tucumán, 2001

Suriano, Juan, "Los dilemas actuales de la historia de los trabajadores", en Jorge Gelman (Comp.) La historia económica en la encrucijada, Buenos Aires, Prometeo, 2006, p. 286

Torre, Juan Carlos, “¿Por qué no existió un fuerte movimiento obrero socialista en la Argentina?”, en Entrepasados, № 35, 2009, pp. 151-163

Torre, Juan Carlos, "La trayectoria de la vieja guardia sindical antes del peronismo", en Waldo Ansaldi, Alfredo Pucciarelli y José Villarroel, José, Representaciones inconclusas. Las clases, los actores y los discursos de la memoria, 1912-1946, Buenos Aires, Biblos, 1995, 296-297.

Torre, Juan Carlos, Ensayos sobre movimiento obrero y peronismo, Siglo XXI, Buenos Aires, 2012. Torre, Juan Carlos, La vieja guardia sindical y Perón, Buenos Aires, Eduntref, 2006

Ullivarri, María, "Del sindicato a la central obrera en una trayectoria de provincia: Tucumán en los años 30", en Archivos de historia del movimiento obrero y la izquierda, Año II, N 4, marzo 2014, Buenos Aires, pp. 123-143.

Ullivarri, María, "El Partido en su laberinto. La Federación Socialista Tucumana, 1931-1937” en

Historia Regional, Sección Historia, ISP N³, Año XXI, N² 26, 2008, pp. 137-164

Ullivarri, María, "Política, antifascismo y movimiento obrero. Tucumán 1935-1936" en Población \& Sociedad, Vol. 16, 2009, pp. 283-316

Ullivarri, María, "Trabajadores, Estado y política durante las gobernaciones radicales en Tucumán. 1935-1943”, Anuario Centro de Estudios Históricos Carlos Segretti, №11, Córdoba, 2011; 
Vidal, Gardenia, Radicalismo de Córdoba 1912-1930. Los grupos internos: alianzas, conflictos, ideas, actores, Córdoba, Universidad Nacional de Córdoba, 1995

Zimmermann, Eduardo, Eduardo, "Sindicatos y política en la Argentina (1900-1943)", en Revista Libertas $\mathrm{N}^{\circ}$ 2, mayo 1985.

\section{Revistas y diarios}

Revista Tierra Libre, Òrgano de la Federación Obrera Local Tucumana, 1922-1936

Boletin CGT-1932-1933

Semanario CGT 1934-1944

Diario La Gaceta de Tucumán, 1923-1944

Diario El Orden de Tucumán, 1927-1943

Diario La Unión de Tucumán, 1942-1944

Revista El Trabajo, 1 número de 1924.

Izquierda, Año 1, Número 2, Noviembre de 1934 